\title{
Adiponectin in Type II Diabetes Mellitus
}

\author{
AHMAD K. MUSTAFA, M.D.; MOHAMMED Z. ABDEL RAHMAN, M.D. and AYAT S. YOUSEF, M.Sc. \\ The Department of Clinical Pathology, Faculty of Medicine, Assiut University
}

\begin{abstract}
Background: Diabetes mellitus is a chronic disorder characterized by impaired metabolism of glucose and lipids due to defect in insulin secretion or action. The association of obesity with development of type 2 diabetes may be partly mediated by altered secretion of adipokines by adipose tissues which may contribute to development of obesity. It has been reported that reduction in plasma adiponectin level may be related to the elevation of insulin resistance.
\end{abstract}

Aim of Study: This study aimed to evaluate the level of adiponectin in patients with type 2 diabetes mellitus.

Subjects and Methods: The current study examined sixty diabetic patients (type 2) with BMI from $30-40 \mathrm{~kg} / \mathrm{m}^{2}$ and 20 age and sex matched healthy controls with BMI from 20-25 $\mathrm{kg} / \mathrm{m}^{2}$

Statistical Analysis: The data were tested for normality using the Anderson-Darling test and for homogeneity variances prior to further statistical analysis.

Results: Adiponectin level was significantly lower in all patients compared to controls. Lipid profile was altered in diabetic patients showing higher levels than in controls. In diabetic patients, adiponectin was significantly positively correlated with High Density Lipoprotein Cholesterol (HDLC), while it was significantly negatively correlated with $\mathrm{HbA}_{1 \mathrm{C}}$, cholesterol, Low Density Lipoprotein Cholesterol (LDL-C), triglyceride and micro-albuminuria.

Conclusion: Adiponectin plays an important role in the patho-physiology of insulin resistance, diabetes, lipid metabolism. Reduction in adiponectin level may be related to the elevation of insulin resistance associated with diabetes milletus type $\Pi$. Adiponectin represents a very important step to understand the mechanism of obesity-induced insulin resistance and atherosclerosis. In contrast to other known adipocytederived hormones that are generally increased in obesity, adiponectin concentrations are that serum adiponectin levels were significantly inversely correlated with cholesterol, triglycerides and $\mathrm{HbA}_{1 \mathrm{c}}$ in type $2 \mathrm{DM}$ patients.

Decreased in obese individuals. This fact together with the promising results of experimental studies suggests the possibility that adiponectin replacement might become a new pharmacological approach to treatment of insulin resistance and/or atherosclerosis so our recommendations are monitoring

Correspondence to: Dr. Ahmad K. Mustafa, The Department of Clinical Pathology, Faculty of Medicine, Assiut University of adiponectin level in diabetic patients is a good predictor of glycemic control and should used in follow-up. Insulin serum level in diabetic patients should be measured to evaluate the effect of adiponectin on insulin level.

Key Words: Diabetes mellitus - Low density lipoprotein cholesterol - High density lipoprotein cholesterol - Body mass index

\section{Introduction}

THE term diabetes mellitus describes a metabolic disorder of multiple aetiology characterized by chronic hyperglycaemia with disturbances of carbohydrate, fat and protein metabolism resulting from defects in insulin secretion, insulin action, or both. The global increase in obesity and greater physical inactivity has been suggested to underlie the alarming rise in the incidence of type 2 diabetes [1]. The association of obesity with development of type 2 diabetes may be partly mediated by altered secretion of adipokines by adipose tissues which may contribute to development of obesity [2]. It has been reported that reduction in plasma adiponectin level may be related to the elevation of insulin resistance [3]. The effects of diabetes mellitus include long-term damage, dysfunction and failure of various organs [4].

Adiponectin, an adipocyte-derived plasma protein, has been shown to play an important role in the regulation of fatty acid and glucose metabolism. Adiponectin enhances fatty acid oxidation both in skeletal and cardiac muscle as well as in the liver, thus reducing triglyceride content in these tissues [5]. Moreover, it stimulates glucose uptake by skeletal and cardiac muscle, and inhibits glucose production by the liver; consequently decreasing blood glucose levels. Adiponectin has effects on carbohydrate and lipid metabolism in skeletal muscle, cardiac muscle and liver. Adiponectin plays an important role in the pathophysiology of insulin resistance, diabetes and dyslipidemia. Reduced 
adiponectin level in plasma or level at baseline was shown to be associated with developing Type 2 Diabetes Mellitus (T2DM) and insulin resistance $[5,6]$.

\section{Subjects and Methods}

This work was carried out during the period from November 2015 to May 2016.

We examined samples of sixty diabetic patients (type 2DM) and 20 age and sex matched healthy controls were included in this study. The patients were selected from the outpatient clinic and inpatients of Internal Medicine Department of Assiut University Hospital. Formal consent was obtained from patients and controls. The study was approved by Ethical Committee of Faculty of Medicine, Assiut University.

Patients with the following conditions were exclued: Smoking habits, hypertension, liver or kidney disorders and those on lipid lowering drug, oral contraceptive pills.

Patients with the following conditions were included: Diabetic patients type II with Body Mass Index (BMI) from 30-40 kg/m².

The following investigations were done for all subjects:

1- Random blood sugar.

2- Complete blood picture.

3- Kidney function test.

4- Micro-albumin in urine.

5- Liver function test.

6- Lipid profile.

7- Glycated hemoglobin $\left(\mathrm{HbA}_{1 \mathrm{C}}\right)$.

8- Serum Adiponectin.

\section{Statistical analysis:}

The data were tested for normality using the Anderson-Darling test and for homogeneity variances prior to further statistical analysis. Categorical variables were described by number and percent $(\mathrm{N}, \%)$, where continuous variables described by mean and standard deviation (mean, SD). Chisquare and fisher exact tests used to compare between categorical variables where compare between continuous variables by unpaired $t$-test. Pearson correlation coefficient used to assess the association between continuous variables. A twotailed $p<0.05$ was considered statistically significant. All analyses were performed with the IBM SPSS 20.0 software.

\section{Results}

Table (1): Comparison between patients and control groups as regards random blood sugar, $\mathrm{HbA}_{1 \mathrm{c}}$ \& Adiponectin.

\begin{tabular}{llll}
\hline & \multicolumn{1}{c}{ Patients } & \multicolumn{1}{c}{ Control } & $p$-value \\
\hline $\begin{array}{l}\text { Random blood } \\
\text { sugar }(\text { mmol/L): }\end{array}$ & & & \\
$\quad$ Mean $\pm \mathrm{SD}$ & $12.02 \pm 2.33$ & $6.48 \pm 0.85$ & $<0.001^{* *}$ \\
$\quad$ Range & $8-17$ & $5-7$ & \\
HbA 1 \% $\%$ & & & \\
$\quad$ Mean $\pm \mathrm{SD}$ & $8.53 \pm 2.82$ & $5.29 \pm 0.68$ & $<0.001^{* *}$ \\
$\quad$ Range & $4.6-15.8$ & $4.3-6.4$ & \\
Adiponectin $(\mu \mathrm{g} / \mathrm{ml}):$ & & & \\
$\quad$ Mean $\pm \mathrm{SD}$ & $3.89 \pm 1.19$ & $8.56 \pm 0.4$ & $<0.001^{* *}$ \\
$\quad$ Range & $1.25-8.3$ & $7.9-9.3$ & \\
\hline
\end{tabular}

Random blood sugar level in patients ranged from $8-17 \mathrm{mmol} / \mathrm{L}$ with mean \pm SD $12.02 \pm 2.33$. In the control it ranged from $5-7 \mathrm{mmol} / \mathrm{L}$ with mean $\pm \mathrm{SD} 6.48 \pm 0.85 . \mathrm{HbA}_{1 \mathrm{c}}$ level in patients ranged from $4.6-15.8 \%$ with mean \pm SD $8.53 \pm 2.82$. In the control group it ranged from $4.3-6.4 \%$ with mean \pm SD 5.29 \pm 0.68 . Adiponectin level in patients ranged from $1.25-8.3 \mu \mathrm{g} / \mathrm{ml}$ with mean \pm SD $3.89 \pm 1.19$. In the control group it ranged from 7.99.3 with mean \pm SD $8.56 \pm 0.4$.

Table (2): Correlation between adiponectin and different parameters in study and control groups.

\begin{tabular}{|c|c|c|c|c|}
\hline & \multicolumn{4}{|c|}{ Adiponectin } \\
\hline & \multicolumn{2}{|c|}{ Patients } & \multicolumn{2}{|c|}{ Control } \\
\hline & $r$ & $p$-value & $r$ & $p$-value \\
\hline Cholesterol & -0.367 & $0.004 * *$ & -0.056 & 0.813 \\
\hline Triglyceride & -0.194 & 0.138 & 0.139 & 0.559 \\
\hline HDL & 0.107 & 0.414 & 0.385 & 0.094 \\
\hline LDL & -0.345 & $0.007 * *$ & -0.269 & 0.251 \\
\hline $\mathrm{HbA}_{1 \mathrm{c}}$ & -0.576 & $0.001 * *$ & 0.217 & 0.358 \\
\hline Micro-Alb & -0.276 & $0.033 *$ & 0.291 & 0.213 \\
\hline
\end{tabular}

Adiponectin level was significantly lower in all patients compared to controls. Lipid profile was altered in diabetic patients showing higher levels than in controls. In diabetic patients, adiponectin was significantly positively correlated with High Density Lipoprotein Cholesterol (HDLC), while it was significantly negatively correlated with $\mathrm{HbA}_{1 \mathrm{C}}$, cholesterol, Low Density Lipoprotein Cholesterol (LDL-C), micro-albumin and triglyceride.

There was statistically significant positive correlations between $\mathrm{BMI}$ and $\mathrm{HbA}_{1 \mathrm{c}}$, random blood sugar, cholesterol and LDL. There was statistically significant negative correlation between BMI and adiponectin. 
Table (3): Correlation between blood sugar, $\mathrm{HbA}_{1 \mathrm{c}}$, MicroAlb, cholesterol, triglyceride, HDL, LDL and adiponectin as regard BMI.

\begin{tabular}{|c|c|c|c|c|}
\hline & \multicolumn{4}{|c|}{ BMI kg/m² } \\
\hline & \multicolumn{2}{|c|}{$30-35 \mathrm{~kg} / \mathrm{m}^{2}$} & \multicolumn{2}{|c|}{$35-40 \mathrm{~kg} / \mathrm{m}^{2}$} \\
\hline & $r$ & $p$-value & $r$ & $p$-value \\
\hline Blood sugar & 0.076 & 0.726 & 0.510 & $0.001 * *$ \\
\hline $\mathrm{HbA}_{1 \mathrm{c}}$ & 0.013 & 0.951 & 0.687 & $0.000 * *$ \\
\hline Micro-Alb & 0.145 & 0.500 & 0.234 & 0.170 \\
\hline Cholesterol & 0.004 & 0.987 & 0.459 & $0.005^{* *}$ \\
\hline Triglyceride & 0.133 & 0.536 & 0.188 & 0.271 \\
\hline HDL & 0.388 & 0.061 & 0.090 & 0.602 \\
\hline LDL & 0.090 & 0.676 & 0.468 & $0.004 * *$ \\
\hline Adiponectin & -0.102 & 0.635 & -0.461 & $0.005^{* *}$ \\
\hline
\end{tabular}

\section{Discussion}

Adiponectin is a collagen-like protein that is solely secreted by adipocytes. Accumulating evidence from animal and human studies demonstrated that Adiponectin played an important role in the pathophysiology of insulin resistance, diabetes, lipid metabolism (Kadowaki et al.) [5] the results of our study showed that all diabetic patients with high BMI $\left(35-40 \mathrm{~kg} / \mathrm{m}^{2}\right)$ have lower concentration of adiponectin and adiponectin is significantly inversely correlated with $\mathrm{BMI}$ and there is significant positive correlations between $\mathrm{BMI}$ and $\mathrm{HbA}_{1 \mathrm{c}}$, random blood sugar, cholesterol and LDL. This in agreement with Weyer et al., [7] Yamamoto et al., [8] and Wei-Siung et al., [9] who reported that adiponectin levels are strongly associated with obesity (increased BMI) and insulin resistance. The association of obesity with development of type 2 diabetes may be partly mediated by altered secretion of adipokines by adipose tissue. Greater adiposity down regulates the secretion of adiponectin [10]. Consequently attempts to reduce body weight to normalize serum adiponectin levels could be effective in preventing the development of diabetes mellitus [11]. In our study we found that Adiponectin level was significantly lower in all diabetic patients (type 2) compared to controls. Lipid profile was altered in diabetic patients showing higher levels than in controls. In diabetic patients, adiponectin was significantly positively correlated with High Density Lipoprotein Cholesterol (HDL-C), while it was significantly negatively correlated with glucose, $\mathrm{HbA}_{1 \mathrm{C}}$, Cholesterol, Low Density Lipoprotein Cholesterol (LDL-C) which is in agreement with Zurawska-klis et al., [12] who found that serum adiponectin levels were significantly inversely correlated with cholesterol, triglycerides and $\mathrm{HbAlc}$ in type $2 \mathrm{DM}$ patients.

\section{Conclusion:}

Adiponectin plays an important role in the patho-physiology of insulin resistance, diabetes, lipid metabolism. Reduction in adiponectin level may be related to the elevation of insulin resistance associated with diabetes milletus type II. Adiponectin represents a very important step to understand the mechanism of obesity-induced insulin resistance and atherosclerosis. In contrast to other known adipocyte-derived hormones that are generally increased in obesity, adiponectin concentrations are decreased in obese individuals. This fact together with the promising results of experimental studies suggests the possibility that adiponectin replacement might become a new pharmacological approach to treatment of insulin resistance and/or atherosclerosis so our recommendations are monitoring of adiponectin level in diabetic patients is a good predictor of glycemic control and should used in follow-up. Insulin serum level in diabetic patients should be measured to evaluate the effect of adiponectin on insulin level.

\section{References}

1- HU F.B.: Globalization of diabetes: The role of diet, lifestyle, and genes. Diabetes Care, 34: 1249-57, 2011.

2- TONJES A., FASSHAUER M., KRATZSCH J., STUMVOLL M. and BLUHER M.: Adipokine pattern in subject with impared fasting glucose and impared glucose tolerance in comparison to normal glucose tolerance and diabetes. Plos One, 5 (11) puplished online: November 2010.

3- LARA-CASTRO C., FU Y., CHUNG B.H. and GARVEY W.T.: Adiponectin and the metabolic syndrome: Mechanisms mediating risk for metabolic and cardiovascular disease. Curr. Opin. Lipidol., 18 (3): 263-70, 2007.

4- World Health Organization (WHO): New Diagnostic Criteria for diabetes, 2011.

5- KADOWAKI, YAMAUCHI T., KUBOTA N., HARA K., UEKI K. and TOBE K.: Adiponectin and adiponectin receptors in insulin resistance, diabetes, and the metabolic syndrome. J. Clin. Invest., 116 (7): 1784-92, 2006.

6- LI Y., L. DING, W. HASSAN, D. ABDELKADER and J. SHANG: Adipokines and hepatic insulin resistance. Journal of Diabetes Research, 170532, 2013.

7- WEYER C., FUNAHASHI T., TANAKA S., et al.: Hypoadiponectinemia in obesity and type 2 diabetes: Close association with insulin resistance and hyperinsulinemia. J. Clin. Endocrinol. Metab., 86: 1930-5, 2001.

8- YAMAMOTO Y., HIROSE H., SAITO I., et al.: Correlation of the adipocyte-derived protein adiponectin with insulin resistance index and serum high-density lipoprotein-cholesterol, independent of body mass index, in the Japanese population. Clin. Sci., 103: 137-42, 2002.

9- WEI-SIUNG Y., WEI-JEI L., FUNAHASHI T., et al.: Plasma adiponectin levels in overweight and obese Asians. Obes. Res., 10: 1104-10, 2002. 
10- HOTTA K., T. FUNAHASHI, ARITA Y., TAKAHASHI M., MATSUDA M., OKAMOTO Y., IWAHASHI H., KURIYAMA H., OUCHI N., MAEDA K., NISHIDA M., KIHARA S., SAKAI N., NAKAJIMA T., HASEGAWA K., MURAGUCHI M., OHMOTO Y, NAKAMURA T., YAMASHITA S., HANAFUSA T. and MATSUZAWA Y.: Plasma concentrations of a novel, adipose-specific protein, adiponectin, in type 2 diabetic patients. Arterioscler. Thromb. Vasc. Biol., 20: 1595-9, 2000.
11- PISCHON T. and RIMM E.: Adiponectin: A Promising Marker for cardiovascular disease, Clinical Chemistry, 52: 797-9, 2006.

12- ZURAWSKA-KLIS M., KASZNICKI J., KOSMALSKI M., ŚMIGIELSKI J. and DRZEWOSKI J.: Adiponectin plasma concentration, type 2 diabetes mellitus, cardiovascular diseases and features of metabolic syndrome. Diabet Do św Klin., 9 (2): 81-7, 2009.

\section{الآديبـونيكتيـن فى داء السكرى النوع الثانى}

الآديبونيكتين هو بروتين يفرز بواسطة الخلايا الشحمية ووجد آنه يلعب دوراً مهماً فى عمليات الآيض المتعلقة بسكر الجلوكوز والدهون حيث يقلل من مستويات سكر الدم والدهون الثلاثية.

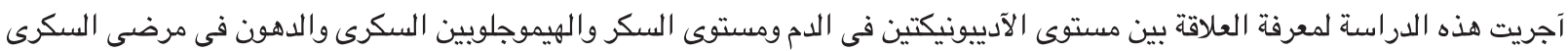

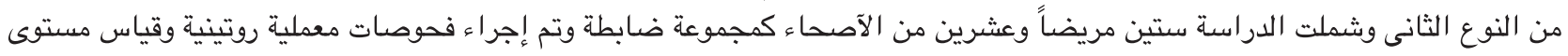

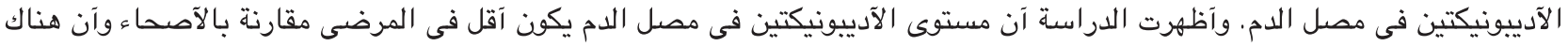

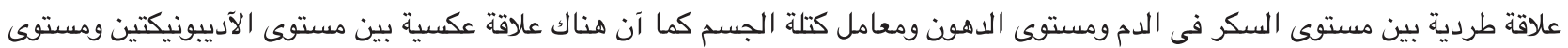

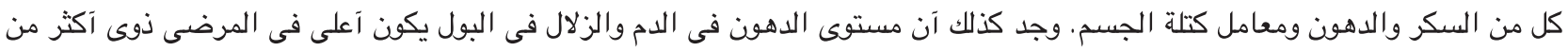

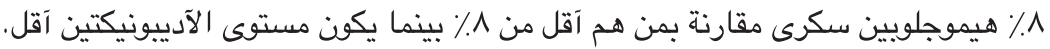

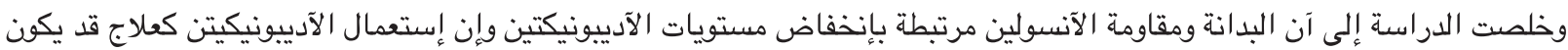

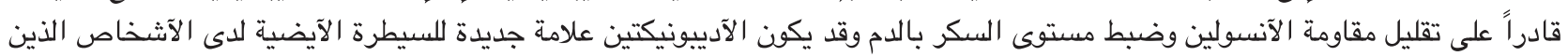
يعانون من مرض السكرى النوع الثانى وهذا قد يجعل الآدييونيكتين آداة علاجية واعدة في المستقبل 